\title{
REHABILITATION OF PERSONS WITH DISABILITIES: THEORETICAL AND LEGAL ASPECT
}

\author{
Triukhan O. A.
}

\section{INTRODUCTION}

The Constitution of Ukraine stipulates that citizens have equal constitutional rights and freedoms and shall be equal before the law. There shall not be any privileges or restrictions on the basis of race, color, political, religious or other beliefs, gender, ethnic and social origin, property status, place of residence, language or other characteristics (art. 24) ${ }^{1}$.

The relevance of the topic of this study is that the interest in the problems of rehabilitation of persons with disabilities has increased in many countries around the world. Unfortunately, disability is a social phenomenon that no society can avoid. According to UNESCO, there were 450 million people with disabilities in the world in 1977, by 1983 this figure had risen to 514 million, and the number of people with disabilities in the world today has reached 1 billion, or $15 \%$ of the population.

The scientific works by the following famous scientists are devoted to the study of certain aspects in the field of rehabilitation of persons with disabilities: V.S. Andreiev, N.B. Bolotna, M.O. Buianova, Ya.I. Bezuhla, V.S. Venediktov, V.M. Dohadov, T.Z. Harasymov, H.S. Honcharov, I.O. Humeniuk, M.L. Zakharova, S.I. Kobzeva, S.I. Bohdanova, O.Ye. Machulska, V.V. Moskalenko, V.P. Melnyk, P.D. Pylypenko, O.I. Protsevskyi, N.M. Stakhovska, Ye.H. Tuchkov, Ya.M. Fohel, M.Y. Fliaster, O.M. Yaroshenko etc. Therefore, taking into account the scientific works and recommendations of scientists, it is advisable to continue research on these issues.

Given the above, the purpose of the study is to determine the theoretical and legal provisions related to the national instruments of the mechanism for rehabilitation of persons with disabilities, to analyze the rehabilitation of the persons with disabilities in Ukraine, to identify the causes and make suggestions for improving legislation in this area.

\section{Rehabilitation of persons with disabilities: theoretical aspect}

Recognition of Ukraine as a welfare state, among other components, means the formation and development of a modern system of social protection of persons with disabilities, which would provide adequate,

\footnotetext{
1 Конституція України : прийнята на п'ятій сесії Верховної Ради України 28 червня 1996 року. Відомості Верховної Ради України. 1996. № 30. Ст. 141.
} 
decent living standards, including a sufficient standard of living for themselves and their families.

It is appropriate to emphasize that in recent years the problem of disability has become especially relevant in Ukraine. Accordingly, there are more than 2.7 million people with disability status in Ukraine, which is 5.2\% of the total population. These figures do not fully reflect the real state of affairs, as a significant number of people with serious health complications do not acquire official status as persons with disabilities, due to the fact that they do not apply to the relevant health care facilities for many reasons. The urgency of this topic is enhanced by the fact that there has been a tendency to significantly increase the number of people with disabilities in recent years in our country. This is observed, in particular, due to the military activity in the East of Ukraine. That is why we believe that the rehabilitation of people with disabilities is one of the urgent problems.

The literature emphasizes that the concept of "disability" is associated with the concept of "incapacity for work". According to the scientist V.S. Andreiev, disability is a medical-certified condition in which a person is forced to stop working for a long time or can work with a significant change of normal working conditions due to a chronic disease or anatomical defects that cause persistent dysfunction, despite treatment ${ }^{2}$.

It should be noted that disability as a category of incapacity for work has a legislative definition; described in the Law of Ukraine "On Rehabilitation of the Persons with Disabilities in Ukraine" No.2961-IV (Art. 1) dated October $6,2005^{3}$. This Law provides for: the establishment of disability groups and the formation of rehabilitation taking into account the expectations of the user; a set of types, forms of rehabilitation, and types of rehabilitation institutions; ensuring persons with disabilities with aids, etc. It should be noted that at that time, the Law was considered quite progressive, but it applied only to persons with disabilities who were formalized through the establishment of the 1st, 2nd, and 3rd disability groups; respectively, its provisions did not particularly apply to persons with disabilities who do not have such a disability group.

As mentioned above, unfortunately, a significant number of people with serious health complications have difficulty obtaining official status as a person with a disability, as evidenced by the case law ${ }^{4}$. Analyzing the case law, we can conclude that the most frequent refusals of MSEC to appoint a disability group are as follows: under-examination, lack of justification of the disease; the absence of some (clarifying) medical records, so it is

${ }^{2}$ Андреев В.С. Право социального обеспечения в СССР. Москва, 1987. 352 с.

3 Про реабілітацію осіб з інвалідністю в Україні : Закон України від 6 жовтня 2005 року № 2961-IV. Відомості Верховної Ради Украӥни. 2006. № 2. Ст. 36.

Рішення Вінницького окружного адміністративного суду у справі № 120/4010/19-a. Єәиний державний реєстр судових рішень. URL: https:/zakononline.com.ua/court-decisions/show/87318719. 
impossible to determine the degree of disability; lack of diagnoses or symptoms, etc. 5 .

With the help of legislation, the social policy of the state is implemented. The main purpose of the legislation, with regard to persons with disabilities, there is, if possible, the most complete social and economic integration of persons with disabilities into the family, team, society. Legislation should take into account constantly changing disability criteria, working and living conditions. Such changes include medical advances, the elimination of diseases that have led to disability, economic conditions, new technologies, and society's progress in understanding the status of persons with disabilities.

We should note that the obligation to determine the state of working capacity in general and the degree of incapacity for work is imposed on MSEC, which is regulated by Resolution of the Cabinet of Ministers of Ukraine No.1317 "Issues of Medical and Social Expertise" dated December 3, 2009. Based on the results of the expertise, MSEC issues a standard certificate indicating the disability group and an individual rehabilitation program to the person recognized as a person with a disability. We should note that the legislation also defines the causes of disability (para. 26) ${ }^{6}$.

It is worth noting that there are 363 MSECs in Ukraine. There are employed about 2,000 people, most of them are doctors. MSEC's state work costs about $160 \mathrm{mln}$ UAH a year. The main task of MSEC is the rehabilitation of persons with disabilities. Regarding the activities of MSEC, it should be noted that this is a charged matter in our country, as indicated in the explanatory note to the draft Law of Ukraine "On Amendments to Certain Laws of Ukraine on Improving Social Protection of Persons with Disabilities in Ukraine" No.4803 dated June 13, 2016 (withdrawn on August 29, 2019), "the activities of such commissions are extremely opaque and closed". MSEC is considered one of the most corrupt institutions in the field of state social policy. It is common to receive a certificate on disability and benefits related to it from MSEC commissions for bribes. There are widespread cases where the rights of people with disabilities, who truly need social protection from the state, are restricted and violated, as evidenced by numerous complaints, publications in the media about corruption and abuse in MSEC. "Today, almost every person with a disability in Ukraine associates the word "MSEC" with emotional humiliation"?

\footnotetext{
5 Рішення Донецького окружного адміністративного суду у справі № 200/600/19-a. Єдиний державний реєстр судових рішень. URL: https://youcontrol.com.ua/catalog/ court-document/81082005.

6 Питання медико-соціальної експертизи : постанова Кабінету Міністрів України від 3 грудня 2009 року № 1317. Офіційний вісник Украӥни. 2009. № 95. Ст. 3265.

7 Про внесення змін до деяких законів України щодо підвищення соціальної захищеності інвалідів в Україні : проєкт Закону України від 13 червня 2016 року № 4803. URL: http://w1.c1.rada.gov.ua.
} 
According to the media, the Unified Register of Court Decisions contains decisions for bribery while receiving a disability status. The media make findings that only one judgment of the court provided for a real term behind bars for a bribe-taker. It is also noted that most of the accused pleaded guilty and came to a plea agreement. They were ordered to pay a fine, but in $40 \%$ of cases it did not exceed the amount of the bribe ${ }^{8}$.

In support of the above, attention should be paid to case law, in particular, case 333/6365/17. Thus, the Kommunarskyi District Court of Zaporizhzhia, considered in open court session criminal proceedings No.42017081020000098 on charges of Person_2 in committing a crime under Part 1 Art. 190 of the CC of Ukraine. The court recognized the head of the department guilty of a crime with a different qualification - under Art. 190 of the CC of Ukraine (fraud) and assigned a fine of $850 \mathrm{UAH}$. We should note that in a court session the accused Person_2 plead guilty to the incriminated crime provided by Part 1 Art. 190 of the CC of Ukraine. In addition, it should be added that the Kommunarskyi District Court of Zaporizhzhia amnestied the head of the Department of General Practice of Family Medicine at the CI "Misla Likarnia No.7" on June 21, $2019^{9}$.

Therefore, we believe that there is a real need to create an independent expert commission, as provided by the draft of Law No.4803 dated June 13, 2016, which, unfortunately, was withdrawn. After all, the draft of Law No.4803 draws attention to the quality of preparation of individual rehabilitation programs for people with disabilities in the MSEC system, which is carried out mainly by health workers; unfortunately, it is at a low level now. After all, individual rehabilitation programs for people with disabilities prepared by MSEC do not contain appropriate measures for social and labor rehabilitation of people with disabilities. In turn, this deprives millions of people with disabilities in Ukraine of opportunities for effective social integration and full life, dooming them to social isolation. In our opinion, the proposal of the author of the draft of Law No.4803 to significantly increase the efficiency of preparation and implementation of individual rehabilitation programs for persons with disabilities, as well as strengthening control over the preparation and implementation of individual rehabilitation plans for persons with disabilities is appropriate. Therefore, it is appropriate to emphasize that the need for law, regarding the increase of social protection of persons with disabilities in Ukraine, is obvious.

8 «Місце торгу та корупції»: розслідування про роботу медико-соціальних експертних комісій. UA: Перший. Автори: Інна Білецька, Дмитро Бондар, Алла Садовник, Олександр Стратонов, Ольга Ульянова. URL: https://4vlada.com/mistsetorgu-ta-koruptsii-rozsliduvannia-pro-robotu-medyko-sotsialnyh-expertnyh-komisij.

${ }_{9}^{9}$ Рішення Комунарського районного суду м. Запоріжжя у справі № 333/6365/17. Єдиний державний реєстр судових рімень. URL: http://www.reyestr.court.gov.ua/ Review/82647944. 
The term "rehabilitation" is used in legal practice for persons restored to their rights and comes from the Latin "reabilitacio" ("restoration"). Despite the widespread use of the term "rehabilitation", today there is no consensus on its use, as well as on the purpose and objectives of rehabilitation measures. One of the first definitions of "rehabilitation" was given by Kurt Winter: "Rehabilitation is a purposeful activity of the team in medical, pedagogical, social and economic aspects in order to preserve, restore and strengthen the ability of a person to take an active part in social life". The most fully and consistently concept of rehabilitation is developed in the works by M.M. Kabanov. The scientist defines rehabilitation as a systemic method of approach to the treatment of the patient ${ }^{10}$. Thus, rehabilitation does not only involve the provision of medical care but includes a wide range of measures and actions, including initial activities (for example, to restore professional capacity).

In the literature, it is noted that rehabilitation, as a concept, is relatively new in human history. The beginning of organizational measures in the rehabilitation of persons with disabilities on an international scale dates back to 1958 when the first meeting of the World Health Organization (hereinafter referred to as WHO) Expert Committee on the Rehabilitation of Persons with Disabilities took place. Later, in 1960, the International Society for the Rehabilitation of Persons with Disabilities was founded; now it is a member of the WHO and works closely with the United Nations and other non-governmental organizations.

At the same time, the essence of the term "rehabilitation of the persons with disabilities" began to be widely discussed at scientific and practical events of specialists in the rehabilitation of the persons with disabilities. Thus, at the International Symposium on the Rehabilitation of the People with Disabilities (1964) the following definition was proposed: "Rehabilitation is the activity of a team of medical workers aimed at restoring the health (in physical, psychological and social terms) and ability to work of the people with disabilities". According to ILO, rehabilitation of people with disabilities means the restoration of their health.

Resolution of the 9th Meeting of the Ministers of Health and Social Welfare of the Persons with Disabilities (Prague, 1967) defines rehabilitation as a system of state socio-economic, medical, and other measures aimed at preventing temporary or permanent incapacity for work, as well as attracting people with disabilities to work, returning them to active social life. The second report of the WHO Expert Committee on the Rehabilitation of Persons with Disabilities (1964) defines the term "rehabilitation" as a set of medical, psychological, pedagogical, social, and other measures aimed at

${ }^{10}$ Кабанов М.М. Психосоціальна реабілітація та соціальна психіатрія. СанктПетербург, 1998. 
restoring the impaired health of the person with disabilities and inclusion of him or her in society and the labor process ${ }^{11}$.

Discussions on the need for social rehabilitation in Ukraine started in the mid-90s of the 20th century. The national legislation stipulates that rehabilitation services are services aimed at restoring the optimal physical, intellectual, mental, and social standard of living of a person in order to promote his or her integration into society. It should be noted that the provision of rehabilitation services is one of the forms of rehabilitation measures. Rehabilitation measures (services) are carried out (provided) exclusively on the basis of individual rehabilitation plans.

It should be noted that today Ukraine has an extensive system of rehabilitation institutions. According to the rehabilitation measures carried out, the legislation stipulates that rehabilitation institutions of the following types: rehabilitation in health care; medical and social rehabilitation; social rehabilitation; psychological and pedagogical rehabilitation; vocational rehabilitation; labor rehabilitation; rehabilitation in physical culture and sports. It is also prescribed that rehabilitation facilities may be of a mixed type.

As of January 1, 2018, there have been more than 400 rehabilitation institutions of various subordination in Ukraine, including 153 under the departmental subordination of the Ministry of Social Policy of Ukraine. Formally, the number of people with disabilities undergoing rehabilitation is not very low. In 2017, more than 19 thousand persons with disabilities and children with disabilities were rehabilitated in rehabilitation institutions under the Ministry of Social Policy of Ukraine, including 3.8 thousand persons with disabilities and children with disabilities were in state rehabilitation institutions ${ }^{12}$.

The second important category in need of rehabilitation services includes the victims of the anti-terrorist operation. According to the Law of Ukraine "On Status of War Veterans, Guarantees of Their Social Protection", the status of a combatant was established for 296,278 persons; disabled war veterans $-5,004$ people; veterans -715 people; military survivors $-7,205^{13}$. In addition, as a result of the anti-terrorist operation, 9,000 civilians acquired health concerns due to hostilities, of which 200 were certified as persons with disabilities ${ }^{14}$.

11 Кондратьева 3.А. К вопросу о понятии социально-трудовой реабилитации. Вопросы сочиального обеспечения. 1986. Вып. 17. С. 37-43.

12 Міністерство соціальної політики України. Соціальний звіт за 2016 рік. Київ, 2017. C. 34. URL: https://www.msp.gov.ua/timeline/Socialni-zviti-.html.

13 Аналітичні матеріали до засідання Ради у справах осіб 3 інвалідністю при Кабінеті Міністрів України 25 травня 2017 року. URL: https://www.msp.gov.ua/timeline/Socialni-zviti-.html.

14 За інформацією УВКБООН та Офісу Уповноваженого Президента 3 прав людей $з$ інвалідністю. URL: https://www.ukrinform.ua/rubric-society/3106434-tetanabarancova-uradova-upovnovazena-z-prav-osib-z-invalidnistu.html. 
Thus, the realities of today, namely, the rapid spread of the COVID-19 pandemic, the emergence of new technologies, the growth of injuries in the workplace, the number of injured in road accidents, necessitate the study of current issues of rehabilitation of persons with disabilities.

\section{Rehabilitation of persons with disabilities: legal aspect}

It should be noted that a number of important international regulations have been adopted. The main legal act at the global level is the Universal Declaration of Human Rights, adopted by the UN General Assembly on December 10, 1948. It should not be mentioned that the UN General Assembly adopted the Declaration of the Rights of Persons with Disabilities on December 9, 1975. It is worth noting that the World Health Organization adopted the International Classification of Disability and Incapacity for Work in 1980. In addition, the UN General Assembly adopted the World Program of Action Concerning Persons with Disabilities on December 3, 1982. This Program was the first internationally adopted attempt to address the issue of disability from two perspectives - the development and protection of human rights. It should also be noted that the World Program of Action Concerning Persons with Disabilities has served as a basis for the development of Standard Rules on the Equalization of Opportunities for Persons with Disabilities. The basic idea of the Standard Rules is that the main responsibility for solving the problems of persons with disabilities lies with the state ${ }^{15}$.

The next document that has played an important role in the development of international cooperation on the rights of persons with disabilities is the Convention on the Rights of Persons with Disabilities (hereinafter referred to as the Convention) and its Optional Protocol, adopted by the UN General Assembly on December 13, 2006 (Resolution 61/106) and entered into force on May 3, $2008^{16}$. A lot of ILO acts are devoted to the social support for workers who have suffered serious injuries as a result of an accident at work or an occupational disease that has led to disability.

We should note that the Convention establishes a number of principles that underlie it, as well as the rules of the Convention determine the right to work (Art. 27).

Among the priority areas of social protection of persons with disabilities, the Convention establishes a system of rehabilitation for the labor market. According to the provisions of the Convention (Art. 26), declaring the right to inclusion and rehabilitation, the member states shall take effective and appropriate measures to enable persons with disabilities to achieve and maintain maximum independence, full physical, mental, social, and

\footnotetext{
${ }^{15}$ Стандартні правила забезпечення рівних можливостей для інвалідів, прийняті резолюцією 48/96 Генеральної Асамблеї ООН 20 грудня 1993 року. URL: http://zakon.rada.gov.

16 Конвенція ООН про права осіб 3 інвалідністю, прийнята резолюцією Генеральної Асамблеї ООН 13 грудня 2006 року. URL: http://zakon.rada.gov.ua. 
professional skills, and full involvement in all aspects of life with the support of other persons with disabilities. To this end, the member states shall organize, strengthen and expand comprehensive inclusion and rehabilitation services and programs, especially in health, employment, education, and social services, in such a way that these services and programs are implemented as early as possible and based on multidisciplinary assessing the needs and strengths of the individual, promoting involvement and inclusion in the local community and in all aspects of society, are voluntary and accessible to persons with disabilities as close as possible to their immediate places of residence, in particular in rural areas. At the same time, the member states shall encourage the development of initial and further training for professionals working in the field of inclusion and rehabilitation services, and shall support the availability, knowledge, and use of assistive devices and technologies related to inclusion and rehabilitation for persons with disabilities.

Finding out the place of the Convention on the Rights of Persons with Disabilities in the system of sources of social security law, V.L. Kostiuk notes that the Convention is the international legal basis for the existence and consolidation of the most important rights of persons with disabilities, sets international standards and social guidelines in the field of protection of the rights of persons with disabilities, and needs deep implementation into national law ${ }^{1 f}$.

It should be noted that the fundamental international legal acts on guaranteeing the rights of persons with disabilities in the field of rehabilitation and labor are the ILO Convention No. 159 on Vocational Rehabilitation and Employment of Persons with Disabilities dated June 1, 1983 and Recommendation No.168 (ratified by Ukraine), etc. ${ }^{18}$. It should be noted that the ILO Convention No.159 on Vocational Rehabilitation and Employment of Persons with Disabilities stipulates that public authorities should promote the employment of persons with disabilities in the following ways: promoting the employment of persons with disabilities in the open labor market (Art. 3); consultations with representative organizations of employers and employees on the implementation of this policy and on measures to be taken to promote cooperation and coordination of public and private bodies engaged in vocational rehabilitation, as well as on consultations with representative organizations of persons with disabilities and in the affairs of such persons (Art. 5); taking measures for the organization and assessment of career guidance, vocational training,

17 Костюк В.Л. Конвенція ООН про права інвалідів у системі джерел права соціального забезпечення: науково-правовий аспект. Науковий вісник Міжнародного гуманітарного університету. Серія «Юриспруденція». 2015. № 13 (1). С. 127-130.

18 Конвенція МОП № 159 про професійну реабілітацію та зайнятість інвалідів від 20 червня 1983 року. URL: http://zakon.rada.gov.ua. 
employment, employment, and other related services so that persons with disabilities have the opportunity to receive, retain employment, and advance in their service; available services for recruitment, in general, should be used where possible and appropriate, with the necessary adaptation (Art. 7); taking measures to promote the establishment and development of vocational rehabilitation and employment services for persons with disabilities in rural and individual areas (Art. 8).

It should also be noted that at the European level the issue of rehabilitation of persons with disabilities is regulated by a number of human rights documents. It should also be noted that at the European level the issue of rehabilitation of persons with disabilities is regulated by a number of human rights documents.

Appropriate attention should be paid to the national legislation, which has a sufficiently strong legal basis to ensure the rehabilitation of persons with disabilities. The basic regulations are the Constitution of Ukraine, the Law of Ukraine "On Rehabilitation of Persons with Disabilities in Ukraine" dated October 6, 2005, the Law of Ukraine "On the Fundamentals of Social Security of Persons with Disabilities in Ukraine" dated March 21, 1991, the Law of Ukraine "On Social services" dated January 17, 2019, and other regulations governing legal relations in this area. In addition, the issue of rehabilitation of persons with disabilities is regulated by a number of bylaws of Ukraine, in particular, the Regulations on issues of medical and social examination, the Regulations on the individual program of rehabilitation and adaptation of persons with disabilities, approved by the Resolution of the Cabinet of Ministers of Ukraine No. 1317 dated December 3, 2009; the Order of the Ministry of Health of Ukraine No. 561 "On Approval of the Instruction on the Establishment of Disability Groups" dated September 5, 2011; the Order of the Ministry of Social Policy of Ukraine No. 1423 "On Approval of Forms of Documents for Sending Certain Categories of Persons for Comprehensive Rehabilitation (Inclusion)" dated September 27, 2018, registered in the Ministry of Justice of Ukraine No. 1160 / 32612 dated October 16, 2018, the Resolution of the Cabinet of Ministers of Ukraine "On Amendments to Certain Resolutions of the Cabinet of Ministers of Ukraine" No. 310 from April 10, 2019, etc.

It should be noted that the right to rehabilitation of persons with disabilities, its structure, and components, the procedure for implementation are determined by the Law of Ukraine "On Rehabilitation of Persons with Disabilities in Ukraine" dated October 6, 2005. According to Art. 1 of the above Law, rehabilitation of persons with disabilities is a system of medical, psychological, pedagogical, physical, professional, labor, physical culture and sports, social and household activities aimed at assisting persons in restoring and compensating for impaired or lost body functions to achieve and maintain social and material independence, labor adaptation and 
integration into society, as well as the provision of persons with disabilities with technical and other means of rehabilitation and medical devices.

Important components of state policy in the field of rehabilitation of persons with disabilities are state social standards in the field of rehabilitation and state standard programs for rehabilitation of persons with disabilities. It should be particularly noted that the right to rehabilitation of persons with disabilities is also determined by the Resolution of the Cabinet of Ministers of Ukraine "On Approval of the Regulations on the Individual Rehabilitation Program for Persons with Disabilities" No.757 dated May 23, 2007. We should emphasize that the individual rehabilitation program for a person with disabilities is a set of optimal types, forms, extents, terms of rehabilitation measures with the definition of the order, place of their implementation, aimed at restoring and compensating for impaired or lost body functions and abilities of a person with a disability and a child with a disability. The program is developed for each person with a disability separately on the basis of the State Standard Rehabilitation Program for Persons with Disabilities No. 1686 dated December $8,2006^{19}$. In addition, the Order of the Ministry of Social Policy No. 855 "Some Issues of Comprehensive Rehabilitation of Persons with Disabilities" dated August 9, 2016, in the version of January 22, 2019 approved the Standard Provisions on the Center for Comprehensive Rehabilitation for Persons with Disabilities and others.

It is noteworthy that in order to implement state policy, a State Standard Program for the Rehabilitation of Persons with Disabilities is developed. The program aims to ensure a systemic approach to the organization of rehabilitation and continuity in conducting multidisciplinary rehabilitation activities, the introduction of state rehabilitation standards, and the establishment of control over the quality of rehabilitation services. The purpose of the Program is to determine the state-guaranteed lists of rehabilitation services, technical and other means of rehabilitation, medical devices provided to a person with disabilities, taking into account the actual needs depending on age, gender, type of disease (injury) free of charge or on preferential terms.

It should be noted that the development of individual rehabilitation programs for people with disabilities is a complex and responsible work because it depends on how well the rehabilitation measures will be selected in each case, whether a person with disabilities can restore health, capacity for work, and integrate into social life. Often the development and implementation of individual rehabilitation programs for people with disabilities face a number of problems, including economic, medical and biological, social and domestic ones.

19 Про затвердження Державної типової програми реабілітації осіб з інвалідністю : затв. Постановою Кабінету Міністрів України від 08 грудня 2006 року № 1686. Офічійний вісник Украӥни. 2006. № 50. Ст. 3311. 
It is worth noting that the rehabilitation of people with disabilities is one of the priorities of modern social policy. Particular attention to the problems of disability and their social protection is due to the fact that their number has increased significantly due to the economic instability of recent years in our country. Judicial practice shows that quite often persons with disabilities apply to the court to declare actions to refuse to adjust the individual rehabilitation program, the obligation to make adjustments in prosthetics in the individual rehabilitation program, illegal, in particular, the decision of the Donetsk District Administrative Court in the case No. 200/8252/19-a, which is referred to the Unified State Register of Court Decisions ${ }^{20}$.

As Jarrold Kaplan rightly points out, successful rehabilitation programs must begin with the prevention of disability. We should note that in Art. 1 of the Law of Ukraine "On Rehabilitation of Persons with Disabilities in Ukraine" disability prevention is recognized as "implementation of a set of medical, hygienic, physical, pedagogical, psychological, professional, and other measures aimed at preventing the transition of disease, injury, or disability, or reducing the severity of the disability.

It is appropriate to emphasize that the financing of rehabilitation measures of the individual program is carried out at the expense of funds provided for this purpose in the state and local budgets, and other sources. However, there are virtually no funds for financing, i.e. all authorities and other institutions involved in the rehabilitation process are often unable to follow the instructions of the medical and social expert commission due to lack of funds. We consider it expedient to agree with the opinion of M. Bahnii, O. Koval, T. Yatskiv, who, analyzing some court cases in their research on this issue, state that judicial practice is to protect the rights of citizens if an individual rehabilitation program is not implemented. In particular, in the case of the citizen's claim to the Department of Labor and Social Protection of the District State Administration on the appointment, calculation and payment of monetary compensation in the implementation of the individual rehabilitation program for the person with disabilities, the claims are motivated by the fact that the citizen was recognized as a person with disabilities of the 1st group and issued an individual rehabilitation program for person with disabilities. The claimant believes that, in accordance with applicable law, this service should be provided to her free of charge, but she has paid for this measure herself. Her appeal to the Department of Labor and Social Protection of the Population of the District State Administration to receive monetary compensation was denied. Given the above, the court considers the claims justified, and the claim is to be

$\begin{array}{cccccc}20 & \text { Рішення } & \text { Донецького окружного адміністративного суду у справі } \\ \text { № 200/8252/19-a. } & \text { Сдиний державний реєстр судових рімень. URL: }\end{array}$ https://youcontrol.com.ua/catalog/court-document/84919488. 
satisfied (http://www.reyestr.court.gov.ua/Review/11598069) ${ }^{21}$. So, as we can see, in this case, the citizen managed not only to issue her an individual rehabilitation program for a person with disabilities including its proper implementation in a judicial procedure. We believe that this is a clear example of how to fight for our rights.

The concept of rehabilitation is closely related to the concept of inclusion. It should be noted that the Law of Ukraine "On Rehabilitation of Persons with Disabilities in Ukraine" No. 2961-IV dated October 6, 2005, determines that inclusion is a system of measures aimed at mastering the knowledge and skills necessary for independent living of a person in a social environment: awareness of his or her abilities and disabilities, social role, understanding of rights and responsibilities, the ability to self-care. In addition to the above Law, the definition of the term inclusion is also contained in the Law of Ukraine "On rehabilitation in health care" dated December 3, 2020 (Art. 1).

It should be noted that the Resolution of the Cabinet of Ministers of Ukraine No. 80 dated January 31, 2007 (as amended by the Resolution of the Cabinet of Ministers of Ukraine No. 587 dated August 1, 2018) approves the Procedure for Providing Certain Categories of Persons with Comprehensive Rehabilitation (Inclusion). It defines the mechanism for providing comprehensive rehabilitation (inclusion) services to persons with disabilities and children with disabilities, or children under the age of three who have the risk for disability (in order to prevent disability ${ }^{22}$. It is worth noting that the Resolution of the Cabinet of Ministers of Ukraine No. 587 dated July 26, 2018 "On Amendments to the Resolutions of the Cabinet of Ministers of Ukraine No. 1686 dated December 8, 2006 and No. 80 dated January 31, 2007 " introduced a number of changes to prevent development of the system for provision of comprehensive rehabilitation (inclusion) and disability prevention (early intervention) services ${ }^{23}$. We should note that this procedure defines the mechanism for providing persons with disabilities and children with disabilities, or children under the age of three who have the risk for disability (to prevent disability) (hereinafter the recipient), with comprehensive rehabilitation services (inclusion). The recipient is provided with comprehensive rehabilitation (inclusion) services in a rehabilitation institution that operates in accordance with the Law of Ukraine "On

${ }^{21}$ Багній М., Коваль О., Яцків Т. Стан медико-соціальної експертизи в Україні та шляхи покращення іiі реалізації: громадський аналіз та рекомендації. URL: https://www.irf.ua/files/ukr/programs/health/ph-2014-1-24.pdf.

${ }^{22}$ Про затвердження Порядку надання окремими категоріями осіб послуг із комплексної реабілітації (абілітації) : Постанова Кабінету Міністрів України від 31 січня 2007 року № 80 (ред. від 1 серпня 2019 року). Офіиійний вісник України. 2007. № 8. Ст. 292.

${ }_{23}$ Про внесення змін до Постанов Кабінету Міністрів України від 08 грудня 2006 року № 1686 і від 31 січня 2007 року № 80 : Постанова Кабінету Міністрів України від 26 липня 2018 року № 587. Офіиійний вісник Украӥни. 2018. № 62. Ст. 2137. 
Rehabilitation of Persons with Disabilities in Ukraine" and other regulations in the field of rehabilitation (inclusion).

The people in Ukraine are now increasingly talking about the need for radical changes in the organization of rehabilitation care. It should be noted that the Verkhovna Rada currently has a draft of Law on Disability Prevention and Rehabilitation System in Ukraine (Registration No. 4458 dated April 15, 2016). We believe that in order to ensure a higher level of social and legal protection of persons with disabilities, it is necessary to adopt an appropriate legislation. Accordingly, the draft of Law (Registration No. 4458) provides for the establishment of a separate procedure for rehabilitation for the following categories of the population: children with disabilities; combatants; persons affected by natural or man-made disasters. We hope that the adoption of the above legislation will strengthen the level of the social and legal protection of this category of persons because the main tasks of rehabilitation are to make a person capable of living in society, to create appropriate conditions for involvement in the social labor process, based on the fact that work is not only a necessary social condition for full human existence but sometimes a decisive factor in the treatment process.

\section{CONCLUSIONS}

Summarizing the previous discussion, we note that today the state has an important task: to create a barrier-free living environment that will enhance the social adaptation of persons with disabilities and allow them to take an active part in public life. It is worth noting that at the present stage, rehabilitation is of special importance (especially in medicine) because it is possible to achieve a positive end result of treatment, to realize the main goal - to return the individual to everyday routines while maintaining quality life activity. In recent years the issues and prospects for the development of rehabilitation services in Ukraine have been widely discussed; it has become especially important due to many patients with gunshot wounds, for whom it is important not only to restore quality of life, but to back on duty. As it is noted above, the problem has been highlighted by the military conflict in eastern Ukraine over the past years.

On the positive side, the Decree of the President of Ukraine "On Improving the Effectiveness of Measures in the Sphere of Rights of Persons with Disabilities" No. 875/2019 dated December 3, 2019 became another regulation concerning the social protection of persons with disabilities, improving their access to medicine, education, work, and the physical environment ${ }^{24}$. In accordance with the Decree of the President of Ukraine No. 87I/2019 "On Improving the Effectiveness of Measures in the

\footnotetext{
24 Про підвищення ефективності заходів у сфері прав осіб 3 інвалідністю : Указ Президента України від 3 грудня 2019 року № 875/2019. URL: https://www.president.gov.ua/documents/8752019-30781.
} 
Sphere of Rights of Persons with Disabilities", there will be created conditions for persons with disabilities to guarantee their rights and freedoms, increase access to social, medical, educational, and other services, environment with no barriers.

Undoubtedly, attention should be also paid to the recently adopted Law of Ukraine "On Rehabilitation in Health Care" dated December 3, 2020. The law defines the legal, organizational, and economic principles of rehabilitation of persons with disabilities of daily functioning in health care in order to achieve and maintain the optimal level of functioning in their environment ${ }^{25}$. It is worth emphasizing the fact that the document introduces the functioning of a modern system of "rehabilitation in health care", i.e. the provision of quality rehabilitation care directly in health care facilities from the very beginning of the disease or injury. The President's Press Office emphasizes that the Law will create conditions for the formation of a modern rehabilitation system in Ukraine in the field of health care, which will operate according to the principles and standards of the European Union, will ensure minimizing the states delimiting life activity and resulting in disabilities, and opportunities to achieve optimal social integration for people with disabilities. At the same time, the document harmonizes the national terminology for rehabilitation in health care with the terms used by the World Health Organization. In particular, the Law of Ukraine "On Rehabilitation in Health Care" dated December 3, 2020, also defined the concept of telerehabilitation, which is the implementation of rehabilitation measures using distance learning, in addition to the concept of rehabilitation, and inclusion.

Some scientists working on this problem, in particular, V.P. Melnyk, note that one of the options for developing legislation, implementing the provisions of the UN Convention on the Rights of Persons with Disabilities is to create and adopt a Code on the Rights of Persons with Disabilities, which would clearly and systematically regulate the social protection of persons with disabilities, including rehabilitation: benefits and guarantees for persons with disabilities in rehabilitation; transparent and accessible mechanisms for the rehabilitation of persons with disabilities in the system of state social protection and social insurance; transparent and accessible mechanisms for the rehabilitation of persons with disabilities in the system of non-governmental social protection; mechanisms for the rehabilitation of persons with disabilities who have suffered injuries as a result of military conflicts; mechanisms of state supervision and public control over the rehabilitation of persons with disabilities. The scientist also emphasizes that the development of the draft Code on the Rights of Persons with Disabilities should be based on the position of leading public organizations of persons

25 Про реабілітацію у сфері охорони здоров'я : Закон України від 3 грудня 2020 року № 1053-ІХ. Офічійний вісник України. 2021. № 3. Ст. 121. 
with disabilities, specialists, experts, legal scholars on social protection ${ }^{26}$. In our opinion, this scientific position deserves support.

Therefore, we can conclude that rehabilitation is the best investment in human health, which can prevent disability and return a person to a full and active life.

\section{SUMMARY}

The paper considers theoretical approaches to the definition of "rehabilitation". The article reviews the main regulatory documents related to the rehabilitation of persons with disabilities at the international and national levels. The analysis of the mechanism of rehabilitation of persons with disabilities is carried out. A number of scientific publications, which contain proposals of scientists to improve long-term legislation on discrimination on the grounds of disability at work, have been studied. The analysis of problems of rehabilitation of persons with disabilities in Ukraine is reviewed. The recommendations for improving the legal regulation of rehabilitation of persons with disabilities have been theoretically justified. Therefore, we can conclude that rehabilitation is the best investment in human health, which can prevent disability and return a person to a full and active life. There are presented general conclusions that the implementation of rehabilitation measures needs to be reformed and improved, as well as proposals for improving the legal regulation in this area.

\section{REFERENCES}

1. Конституція України : прийнята на п’ятій сесії Верховної Ради України 28 червня 1996 року. Відомості Верховної Ради Украӥни. 1996. № 30. Ст. 141 .

2. Андреев В.С. Право социального обеспечения в СССР. М., 1987. $352 \mathrm{c}$.

3. Про реабілітацію осіб з інвалідністю в Україні : Закон України від 06 жовтня 2005 року № 2961-IV. Відомості Верховної Ради України. 2006. № 2. Ст. 36.

4. Рішення Вінницького окружного адміністративного суду у справі № 120/4010/19-а. Єдиний державний реєстр судових рімень. URL: https://zakononline.com.ua/court-decisions/show/87318719.

5. Рішення Донецького окружного адміністративного суду у справі № 200/600/19-а. Єдиний державний реєстр судових рімень. URL https://youcontrol.com.ua/catalog/court-document/81082005.

26 Мельник В.П. Законодавчі засади правового регулювання реабілітації інвалідів: сучасний стан та напрями удосконалення. URL: file:///C:/Users/\%D0\%9E\%D0\%BA\%D1\%81\%D0\%B0\%D0\%BD\%D0\%B0/Downloads/ Choasp_2014_2_22\%20(1).pdf. 
6. Питання медико-соціальної експертизи : постанова Кабінету Міністрів України від 3 грудня 2009 року № 1317. Офіиійний вісник Украӥни. 2009. № 95. Ст. 3265.

7. Про внесення змін до деяких законів України щодо підвищення соціальної захищеності інвалідів в Україні : проєкт Закону України від 13 червня 2016 року № 4803. URL: http://w1.c1.rada.gov.ua.

8. «Місце торгу та корупції»: розслідування про роботу медикосоціальних експертних комісій. UA: Перший. Автори: Інна Білецька, Дмитро Бондар, Алла Садовник, Олександр Стратонов, Ольга Ульянова. URL: https://4vlada.com/mistse-torgu-ta-koruptsiirozsliduvannia-pro-robotu-medyko-sotsialnyh-expertnyh-komisij.

9. Рішення Комунарського районного суду м. Запоріжжя у справі № 333/6365/17. Єдиний державний реєстр судових рімень. URL: http://www.reyestr.court.gov.ua/Review/82647944.

10. Кабанов М.М. Психосоціальна реабілітація та соціальна психіатрія. Санкт-Петербург, 1998. 240 с.

11. Кондратьева 3.А. К вопросу о понятии социально-трудовой реабилитации. Вопросы сочиального обеспечения. 1986. Вып. 17. С. 37-43.

12. Міністерство соціальної політики України. Соціальний звіт за 2016 рік. Київ, 2017. С. 34. URL: https://www.msp.gov.ua/ timeline/Socialni-zviti-.html.

13. Аналітичні матеріали до засідання Ради у справах осіб 3 інвалідністю при Кабінеті Міністрів України 25 травня 2017 року. URL: https://www.msp.gov.ua/timeline/Socialni-zviti-.html.

14. За інформацією УВКБ ООН та Офісу Уповноваженого Президента з прав людей з інвалідністю. URL: https://www.ukrinform.ua/ rubric-society/3106434-tetana-barancova-uradova-upovnovazena-z-pravosib-z-invalidnistu.html.

15. Стандартні правила забезпечення рівних можливостей для інвалідів, прийняті резолюцією 48/96 Генеральної Асамблеї ООН 20 грудня 1993 року. URL: http://zakon.rada.gov.

16. Конвенція ООН про права осіб 3 інвалідністю, прийнята резолюцією Генеральної Асамблеї ООН 13 грудня 2006 року. URL: http://zakon.rada.gov.ua.

17. Костюк В.Л. Конвенція ООН про права інвалідів у системі джерел права соціального забезпечення: науково-правовий аспект. Науковий вісник Міжнародного гуманітарного університету. Серія «Юриспрудениія». 2015. № 13 (1). С. 127-130.

18. Конвенція МОП № 159 про професійну реабілітацію та зайнятість інвалідів від 20 червня 1983 року. URL: http://zakon.rada.gov.ua.

19. Про затвердження Державної типової програми реабілітації осіб 3 інвалідністю : затв. Постановою Кабінету Міністрів України від 
8 грудня 2006 року № 1686. Офіційний вісник Украӥни. 2006. № 50. Ст. 3311.

20. Рішення Донецького окружного адміністративного суду у справі № 200/8252/19-а. Єдиний державний реєстр судових рішень. URL: https://youcontrol.com.ua/catalog/court-document/84919488.

21. Багній М., Коваль О., Яцків Т. Стан медико-соціальної експертизи в Україні та шляхи покращення іiі реалізації: громадський аналіз та рекомендації. URL: https://www.irf.ua/files/ukr/programs/health/ ph-2014-1-24.pdf.

22. Про затвердження Порядку надання окремими категоріями осіб послуг із комплексної реабілітації (абілітації) : Постанова Кабінету Міністрів України від 31 січня 2007 року № 80 (ред. від 1 серпня 2019 року). Офіційний вісник України. 2007. № 8. Ст. 292.

23. Про внесення змін до Постанов Кабінету Міністрів України від 8 грудня 2006 року № 1686 і від 31 січня 2007 року № 80 : Постанова Кабінету Міністрів України від 26 липня 2018 року № 587. Офіційний вісник Украӥни. 2018. № 62. Ст. 2137.

24. Про підвищення ефективності заходів у сфері прав осіб з інвалідністю : Указ Президента України від 3 грудня 2019 року № 875/2019. URL: https://www.president.gov.ua/documents/8752019-30781.

25. Про реабілітацію у сфері охорони здоров'я : Закон України від 3 грудня 2020 року № 1053-IX. Офіиійний вісник України. 2021. № 3. Ст. 121.

26. Мельник В.П. Законодавчі засади правового регулювання реабілітації інвалідів: сучасний стан та напрями удосконалення. URL: file:///C:/Users/\%D0\%9E\%D0\%BA\%D1\%81\%D0\%B0\%D0\%BD\%D 0\%B0/Downloads/Choasp_2014_2_22\%20(1).pdf.

\section{Information about the author: Triukhan O. A.,}

Candidate of Juridical Sciences, Associate Professor, Senior Lecturer at the Department of Labour Law and Social Security Law National University "Odesa Law Academy" 23, Fontanska doroha str., Odesa, 65009, Ukraine 